\title{
SELECTION OF MODES OF HIGH-TEMPERATURE TEMPERING OF HEAT-RESISTANT STEEL WELDED JOINTS MADE BY ELECTRODES THERMANIT MTS616
}

\author{
V.Yu. SKULSKY, A.K. TSARYUK, A.R. GAVRIK, M.A. NIMKO and G.N. STRIZHIUS \\ E.O. Paton Electric Welding Institute, NASU \\ 11 Kazimir Malevich Str., 03680, Kiev, Ukraine. E-mail: office@paton.kiev.ua
}

\begin{abstract}
One of the problems in producing the welded joints of complexly-alloyed heat-resistant steels is the providing of the required level of weld metal impact toughness. The improvement of its ductility and toughness is attained by a postweld high-temperature tempering using the modes regulated by the developer of welding electrodes. In case of welding of an experimental high-chromium martensite steel by electrodes Thermanit MTS616 (10Kh9V2MFB type) with account for conditions of its fulfillment, the heat treatment was required by $30-40{ }^{\circ} \mathrm{C}$ lower than that usually applied for welds of the mentioned type. The effect of modes of the manual arc welding and duration of tempering at $730-720^{\circ} \mathrm{C}$ on hardness and impact toughness of weld metals was determined. Intervals of holdings were found in tempering, during which the secondary hardening was observed. The modes were selected, providing the required level of impact toughness of welds (impact energy $K V \geq 41 \mathrm{~J}$ ). It is shown that alongside with the selected duration of temperature the important factor, providing the increase in toughness of the deposited metal, is the application of multi-pass welding at the reduced energy input. 11 Ref., 4 Figures.
\end{abstract}

Ke y w ord s: heat-resistant martensite steel, manual arc welding with covered electrodes, weld metal, high-temperature heat treatment, tempering mode, hardness, impact toughness

The producing of welded joints of hardening heat-resistant steels is connected with the need in postweld high-temperature heat treatment. The purpose of this operation is the providing of equilibrium state (tempering) to hardening structures, imparting the required mechanical properties to welded joints and relieving of residual stresses. Moreover, one of the problems, to which a special attention is paid during tempering of martensite steels with an increased chromium content, is the providing of the required level of impact toughness of weld metal, for example, for welds with $9 \% \mathrm{Cr}$ at impact energy of $K V \geq 41 \mathrm{~J}$ at $20{ }^{\circ} \mathrm{C}$ (at Charpy test of specimens that corresponds to the specific energy of fracture $K C V \approx 51 \mathrm{~J} / \mathrm{cm}^{2}$ ) [1, 2].

To guarantee the obtaining of high values of impact toughness the positive factor is the increase in temperature and holding duration at tempering. By this reason, if there is no special conditions as to the possible change in steel properties, the tempering is made at temperature of the base metal tempering at the stage of its producing. To avoid the additional reduction of strength properties of base metal the postweld tempering is specified by $20-40{ }^{\circ} \mathrm{C}$ below the temperature used in base metal producing [3].

The similar situation occurred in welding of one of the experimental martensite steels with increased content of chromium in the scopes of investigations, carried out by the project Z-Ultra of the $7^{\text {th }}$ Europe- an program [4]. The electrodes Thermanit MTS616 (Bohler Thyssen Schweisstechnik) with a martensite deposited metal of 10Kh9V2MFB type were selected for welding. The recommended tempering for such metal of welds consisted in holding at $760{ }^{\circ} \mathrm{C}$ for $2 \mathrm{~h}$ [5]. The developer of the experimental steel specified the tempering of welded joints of not higher than 730$720{ }^{\circ} \mathrm{C}$ with account for its heat treatment condition. The need occurred in checking the feasibility of providing the required level of the impact toughness of welds at the above-mentioned tempering conditions.

The aim of the work was in selection of the mode of heat treatment of welded joints of heat-resistant steel with a martensite weld of MTS616 (10Kh9V2MFB) type at the temperature, being lower than that recommended by the developer of welding electrodes.

During experiments the properties of weld metals were studied, produced in manual arc welding of butt joints of $20 \mathrm{~mm}$ thick plates by electrodes Thermanit MTS616 of $3.2 \mathrm{~mm}$ diameter. Chemical composition of metal deposited by electrodes Thermanit MTS616 is following, wt\%: $0.11 \mathrm{C}, 0.19 \mathrm{Si}, 0.63 \mathrm{Mn}, 0.016 \mathrm{P}$, $0.006 \mathrm{~S}, 8.5 \mathrm{Cr}, 0.56 \mathrm{Mo}, 0.57 \mathrm{Ni}, 0.18 \mathrm{~V}, 1.58 \mathrm{~W}$, $<0.1 \mathrm{Cu}, 0.055 \mathrm{Nb}, 0.044 \mathrm{~N}$. As a base metal, the steel was used, somewhat differing from the system of alloying the metal, deposited by the selected electrodes. To avoid the stirring of steel and electrode metal the plate edges were lined with metal of MTS616 type. 

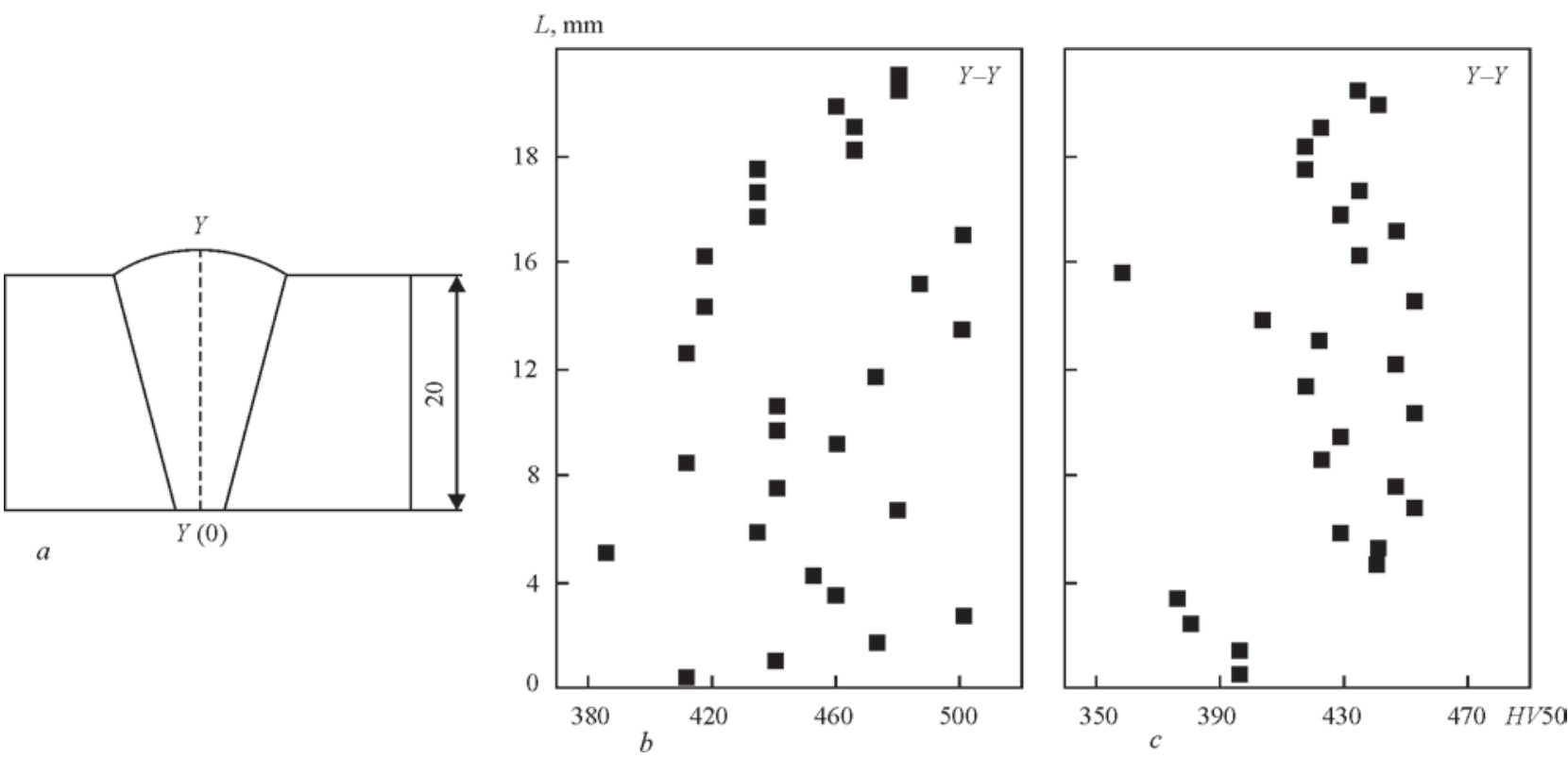

Figure 1. Change in hardness in the center of welds: $a$ - zone of measurement; $b, c$ - results for $I_{\mathrm{w}}=100$ and 120 A, respectively (point $Y(0)$ in root pass corresponds to zero mark)

Such approach allowed evaluating the properties of «purely» electrode metal. The effect of tempering duration (in the ranges from 4 up to $12 \mathrm{~h}$ ) at 720 and $730{ }^{\circ} \mathrm{C}$ on hardness and impact toughness of weld metal at room temperature was determined. Hardness was measured by using Vickers method at $5 \mathrm{~kg}$ load to indenter. The impact bend tests were performed by using $10 \times 10 \mathrm{~mm}$ section specimens with a sharp notch (type IX by GOST 6996-66).

In practice the producing of joints of hard-toweld heat-resistant steels is recommended by welding of beads of small thickness at the lowered modes to attain the improved values of the weld metal impact toughness $[6,7]$. This provides the producing of fine-crystalline primary structure, as well as a partial tempering of layers, made earlier, during laying out of next beads. The subsequent high tempering of welds with a disoriented crystalline microstructure and with a partially improved toughness allowed reaching the required level of the impact toughness values. The similar approach was used in the present work.

Preliminary the experiments were carried out for selection of welding modes providing a stable burning of electrodes, quality weld formation, good fusion of deposited and base metal, easy performance of welding process and beads of small thickness. The experiments showed that in welding at lowered current (80-90 A) minimum possible for the stable arcing it is more complicated to provide the fusion of metal being deposited and edges of steel being welded. Here, to have a good formation of the quality bead, welding should be performed at a low speed. Under such conditions the energy input $q / v$ can have the more higher values than in case of welding at high current, because in the latter case the increase in rate of electrode melting allows increasing the welding speed without deterioration of the forming weld quality. It was found that the optimum is the welding current in the range of 100-120 A. For the conditions and welding procedure used in experiments the energy input for $I_{\mathrm{w}}=100$, A was $q / v=5.15 \mathrm{~kJ} / \mathrm{cm}$, for $I_{\mathrm{w}}=120 \mathrm{~A} q / v=3.29 \mathrm{~kJ} /$ $\mathrm{cm}$. Current of more than 130-140 A leads to a great overheating of the electrode rod, damage of coating and strong spattering.

The evaluation of nature of change in hardness along the vertical axis $Y-Y$ in cross section of welds in the as-welded state showed (Figure 1) that the weld metal made at 120 A current is more homogeneous, the values of hardness have a less scattering than in case of welding at $100 \mathrm{~A}$ current. As a whole, it can be noted that in the given type of welds the metal reaction to thermal tempering effect is weakly manifested in making the next passes. Under the effect of repeated heating the hardness is decreased negligibly and remained at the level close to the state of hardened martensite (HV50-420-500 in welding at $I_{\mathrm{w}}=100 \mathrm{~A}$ and about HV50-400-450 at $I_{\mathrm{w}}=120$ A).

Figures 2 and 3 present the results of evaluation of effect of a long-term tempering at 720 and $730{ }^{\circ} \mathrm{C}$ on values of toughness $(K C V, K V)$ and hardness of weld metals produced at currents 100 and $120 \mathrm{~A}$. The measurements of hardness were made in four regions of the weld cross section, located from one another approximately by $1 / 4$ of joint thickness (according to scheme in Figure 2,a). In all the cases after heat treatment the hardness of welds was in compliance with the requirements of DIN EN ISO 15614-1 [8]. It was less than $H V 350$ according to the standard for the 

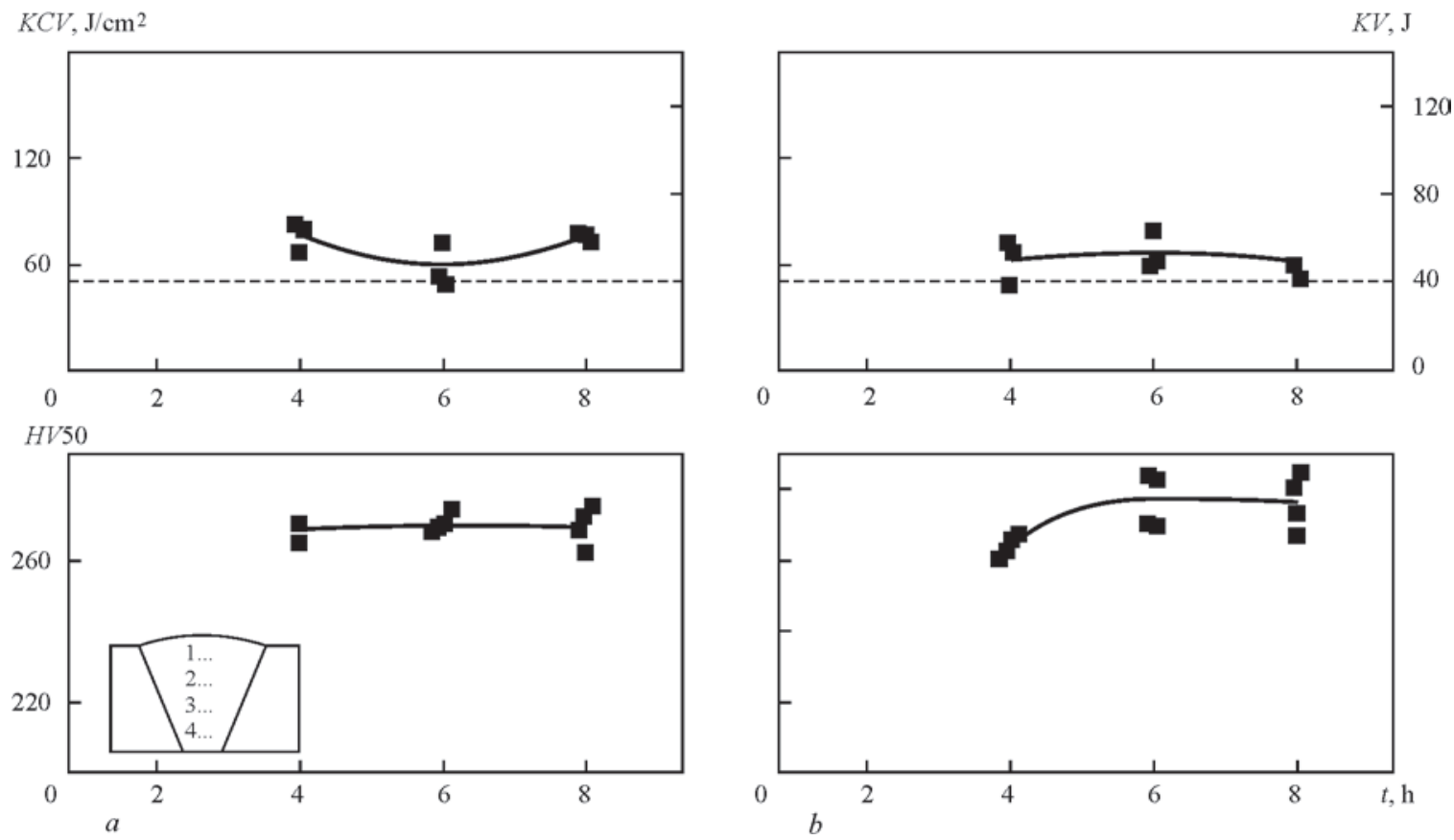

Figure 2. Effect of tempering mode on impact toughness and hardness of weld metal produced at $I_{\mathrm{w}}=100 \mathrm{~A}: a-$ tempering at 720 ; $b-730{ }^{\circ} \mathrm{C}$

joints of steels of group 6 (DIN CEN ISO/TR 15608 [9]), to which the metal of welds of the studied type is belonged. The values of impact toughness exceeded also the minimum allowable level (it is shown in diagrams by a horizontal intermittent line). However in weld made at $120 \mathrm{~A}$ the values of impact toughness were higher than in welds at $100 \mathrm{~A}$ current. This is, probably, connected with the higher homogeneity of deposited metal and more effective tempering of layers, made earlier, under the influence of the repeated welding heating. By this reason the condition of the
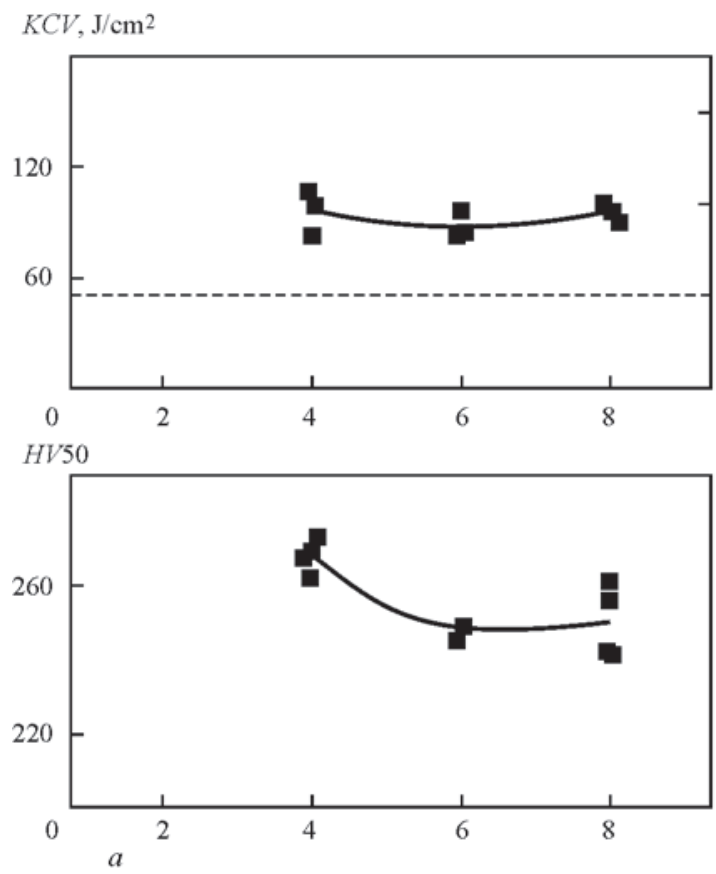

multi-pass welding at $120 \mathrm{~A}$ current can be considered as more preferable.

As is seen from Figure 3, the hardness of welds, made at $120 \mathrm{~A}$, after tempering at $720{ }^{\circ} \mathrm{C}$ for $4 \mathrm{~h}$ is at the higher level than that after the longer holding. Coming from the nature of change in hardness, the duration of tempering at this temperature, equal to about $5 \mathrm{~h}$, can be taken as an acceptable one. Moreover, the sufficiently high impact toughness at the level of $100 \mathrm{~J} / \mathrm{cm}^{2}$ is provided.
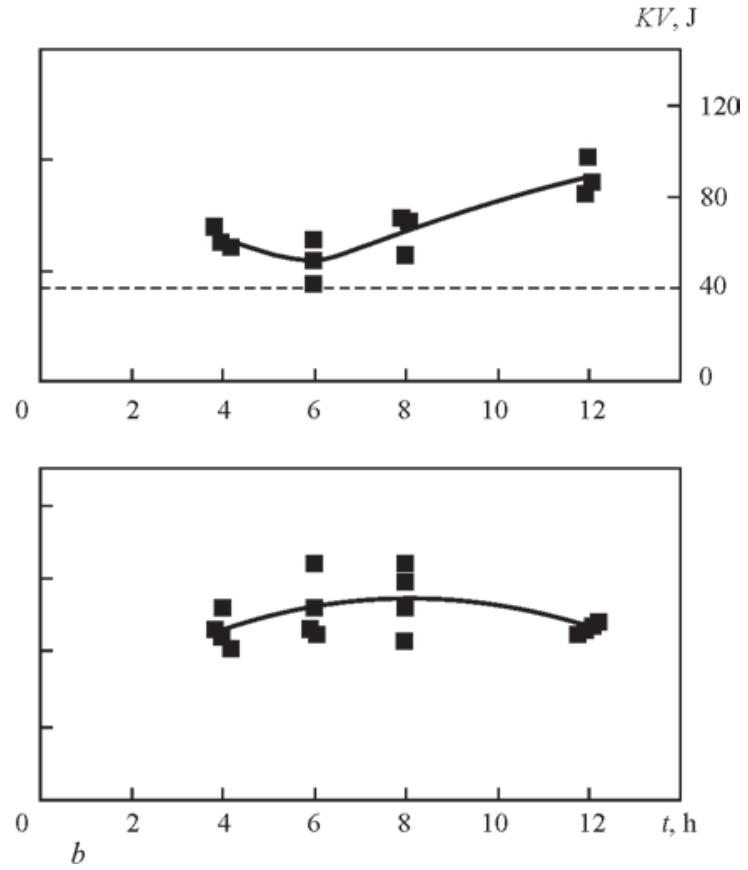

Figure 3. Effect of tempering mode on impact toughness and hardness of weld metal produced at $I_{\mathrm{w}}=120$ A: $a-$ tempering at 720 ; $b-730{ }^{\circ} \mathrm{C}$ 


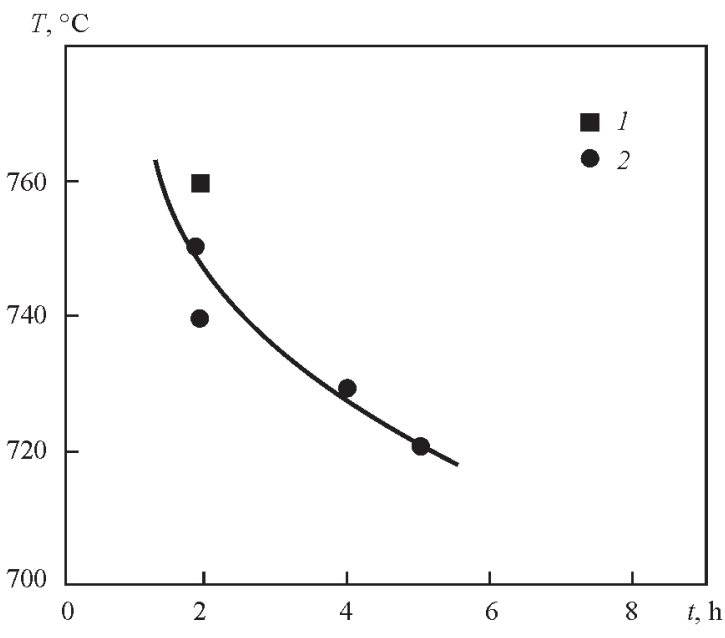

Figure 4. Temperature versus holding at high tempering to provide the required impact toughness of metal of welds in manual arc welding: 1 - recommendations of electrode manufacturer; 2 - results of experiments

During tempering at $730^{\circ} \mathrm{C}$ and holding for more than $4 \mathrm{~h}$ the tendency to the secondary hardening was manifested in both types of studied welds (welded at 100 and 120 A modes). In this case, KCV values decreased noticeably in welds, made at 120 A current, which began to increase again after holding for $8 \mathrm{~h}$ and more. Taking into account that the high-temperature treatment is a power-consuming and an expensive operation, the tempering at possible lower holdings is economically more profitable. Therefore, in case of heat treatment at $730{ }^{\circ} \mathrm{C}$ it is rational to apply holding of about $4 \mathrm{~h}$. After this tempering mode the $\mathrm{KCV}$ values reach the level of approximately $80 \mathrm{~J} / \mathrm{cm}^{2}$. The same tempering modes can be applied also for the welds made at $100 \mathrm{~A}$ current, however, as the obtained results showed, in this case the welds have the lower impact toughness (at the level of about $60 \mathrm{~J} / \mathrm{cm}^{2}$ ).

As a general conclusion, Figure 4 presents the dependence showing the relation between the temperature and holding duration in the process of high tempering, at which the impact energy of metal of welds is provided being of not lower than the minimum value $41 \mathrm{~J}$.

It should be noted that in some cases in evaluation of weld metal properties the $K V$ value of $27 \mathrm{~J}$ is used as a criterion of admissible value of the impact toughness [10]. This $K V$ value was regulated for the cross section of seamless pipes of heat-resistant steels (see, for example, standard BS EN 1021602:2002 [11]). However, in our opinion, the application of this criterion for welds is seemed to be discussible. The lowered toughness in cross section of pipe wall in case of abrupt increase in acting loads (which are formed, for instance, in testing of pipe systems at hydraulic tests or putting the high-temperature components into operation) can cause more probably the fracture in the form of delamination without a through damage. The same lower toughness of weld metal with a cast structure can cause its transverse fracture, which is a rather hazardous defect. Therefore, the authors of the given work made all efforts to provide the higher values of impact toughness of weld metals, taking into account the requirement $K V \geq 41 \mathrm{~J}$.

Thus, the carried out investigations showed the feasibility of providing the requirement to the impact energy of $K V \geq 41 \mathrm{~J}$ of metal of the martensite weld of 10Kh9V2MFB type, made by manual arc welding with electrodes Thermanit MTS616, using tempering at temperature by $30-40{ }^{\circ} \mathrm{C}$ lower than it is recommended by the developer of electrodes. The conditions of providing the required level of toughness are the following:

- multi-pass welding by small beads at modes with lowered energy input (for example 3.3-5.1 kJ/ $\mathrm{cm}$ in welding with electrodes of $3.2 \mathrm{~mm}$ diameter);

- high-temperature postweld heat treatment at $730-720^{\circ} \mathrm{C}$ for $4-5 \mathrm{~h}$.

1. Bergquist, E.-L. (1999) Consumables and welding modified $9 \mathrm{Cr}-1 \mathrm{Mo}$ steel. Svetsaren, 1/2, 22-25.

2. Hoiser, G. (1997) Filler materials for welding in power machine building. Avtomatich. Svarka, 9, 40-44, 47.

3. Petrov, G.L., Zemzin, V.N., Gonserovsky, F.G. (1963) Welding of heat-resistant stainless steels. Moscow: Mashgiz.

4. Z phase strengthened steels for ultra-supercritical power plants. $h t t p: / / w w w . z-u l t r a . e u$

5. (2005) Welding filler metals. Welding guide. Hamm: Boehler Thyssen Schweisstechnik.

6. Rosenbrock, L.A. (2001) A critical overview of the welding of P91 material. Australian Welding J., 46(2 ${ }^{\text {nd }}$ Quart.), 5-8.

7. Adam., W., Mischok, W., Wellnitz, G. et al. (1994) Welding of new types of steel for power plant construction. In: Proc. of Conf. on Welding and Cutting (Germany, Bremen, 28-30 Sept. 1994). Boehler Welding Special Add.

8. DIN EN ISO 15614-1: Anforderung und Qualifizierung von Schweissverfahren fuer metallische Werkstoffe - Schweissverfahrenspruefung. Teil 1: Lichtbogen- und Gasschweissen von Staehlen und Lichtbogenschweissen von Nickel und Nickellegierungen. Deutsche Fassung prEN ISO 15614-1:2013.

9. DIN CEN ISO/TR 15608: Schweissen - Richtlinien fuer eine Gruppeneinteilung von metallischen Werkstoffen. Deutsche Fassung CEN ISO/TR 15608:2013.

10. Mokhila, P., Foldynova, K. (2014) Influence of postweld heat treatment on mechanical properties of R92 steel welded joints made by submerged-arc welding. Metallovedenie i Termich. Obrab. Metallov, 4, 36-39.

11. BS EN 1021602:2002: Seamless steel tubes for pressure purposes. Technical delivery conditions. Pt. 2: Non-alloy steel tubes with specified elevated temperature properties. CEN, 2007. 